\title{
Efficacy of 18F-2-fluoro-2-deoxy-D-glucose Positron Emission Tomography/Computerized Tomography for Bone Marrow Infiltration Assessment in the Initial Staging of Lymphoma
}

\author{
I8F-2-fluoro-2-deoksi-D-glukoz Pozitron Emisyon Tomografisi/Bilgisayarlı Tomografinin \\ Lenfomanın Inisiyal Evrelemesinde Kemik lliği Tutulumunun Belirlenmesindeki Rolü
} \author{
Akın Yıldız', Fırat Güngör ${ }^{3}$, Levent Undar4 \\ I Afyon Kocatepe University Faculty of Medicine, Department of Nuclear Medicine, Afyonkarahisar, Turkey \\ 2Antalya Training and Research Hospital, Clinic of Nuclear Medicine, Antalya, Turkey \\ ${ }_{3}^{3}$ Akdeniz University Faculty of Medicine, Department of Nuclear Medicine, Antalya, Turkey \\ ${ }^{4}$ Akdeniz University Faculty of Medicine, Department of Hematology, Antalya, Turkey \\ 5 Akdeniz University Faculty of Medicine, Department of Pathology, Antalya, Turkey \\ 6 Marmara University Faculty of Medicine, Department of Hematology, İstanbul, Turkey
}

Ali Ozan Önerl, Evrim Sürer Budak², Funda Aydın³, Ozan Salim4, Orhan Kemal Yücel4, Bahar Akkaya 5, Tayfur Toptaş6, Adil Boz³,

\begin{abstract}
Objective: Currently 18F-2-fluoro-2-deoxy-D-glucose (18F-FDG) positron emission tomography/computerized tomography (PET/CT) is being successfully used for staging and follow-up of Hodgkin's lymphoma (HL) and non-Hodgkin's lymphoma (NHL). Various studies have demonstrated that PET/CT effectively detects bone marrow involvement (BMI) and is concordant with bone marrow biopsy (BMB) findings, thus it is deemed as a complementary method. This study was aimed to evaluate ${ }^{18} \mathrm{~F}-$ FDG-PET/CT efficiency for detection of BMI in $\mathrm{HL}$ and NHL.

Methods: The study included 172 lymphoma cases who were admitted to Akdeniz University Medical School Department of Nuclear Medicine for initial staging with PET/CT. Visual and semiquantitative assessments were performed for PET/CT scan findings of the cases. The maximum standard uptake (SUV $V_{\text {max }}$ ) value was the quantitative parameter used for 18F-FDG-PET scan. In visual assessment, bone marrow metabolic activity that is greater than the liver was considered as pathologic. For semiquantitative assessment, regions of interest were drawn for SUV $V_{\max }$ estimation, which included iliac crest in cases with diffusely increased metabolic activity and the highest activity area in cases with focal involvement. BMB was considered as the reference test.

Results: On visual assessment of all the cases, PET/CT was found to yield $31 \%$ sensitivity and $85 \%$ specificity rate for detection of BMI. On visual assessment of $\mathrm{HL}$ cases, sensitivity rate was determined as $80 \%$, and specificity as $78 \%$, while in $\mathrm{NHL}$ cases the corresponding values were $24 \%$ and $90 \%$, respectively. On semiquantitative assessment of HL cases, considering SUV $V_{\text {max }} \geq 4$, sensitivity was found as $80 \%$ and specificity as $68 \%$. In NHL patients, considering $S U V_{\text {max }} \geq 3.2$, sensitivity rate was detected as $65 \%$ and specificity as $58 \%$.

Conclusion: In this study, a moderately high concordance was observed between PET/CT and BMB findings. PET/CT appears to be a significant method for detecting BMI. Although PET/CT is not a substitute for BMB, we suggest it can be used as a guide to biopsy site and a complementary imaging technique for BMB.

Keywords: Hodgkin's lymphoma, non-Hodgkin's lymphoma, positron emission tomography/computerized tomography, bone marrow biopsy
\end{abstract}

Address for Correspondence: Funda Aydın MD, Akdeniz University Faculty of Medicine, Department of Nuclear Medicine, Antalya, Turkey Phone: +90 2422496000 E-mail: afunda12@gmail.com Received: 28.09.2016 Accepted: 18.02.2017 


\section{Öz}

Amaç: Günümüzde 18F-2-fluoro-2-deoksi-D-glukoz (18F-FDG) pozitron emisyon tomografisi/bilgisayarlı tomografi (PET/BT), Hodgkin lenfoma $(\mathrm{HL})$ ve non-Hodgkin lenfomaların (NHL) evrelemesinde ve takibinde başarılı bir şekilde kullanılmaktadır. Değişik çalışmalarda PET/BT'nin kemik iliği tutulumunu göstermede etkinliği ve kemik iliği biyopsisi (Kỉ) ile uyumu gösterilmiş ve tamamlayıcı yöntem olarak kullanılması önerilmiştir. Biz de bu çalışmada HL ve NHL'de kemik iliği infiltrasyonunu değerlendirmede PET/BT'nin etkinliğini değerlendirmeyi amaçladık.

Yöntem: Çalışmaya Akdeniz Üniversitesi Tıp Fakültesi Nükleer Tıp Anabilim Dalı́nda başlangıç evreleme için PET/BT tetkiki yapılan 172 lenfoma olgusu dahil edilmiştir. Olguların PET/BT tetkikinde görsel ve semikantitatif değerlendirme yapıldı. ${ }^{18 F-F D G-~}$ PET tetkikinde kantitatif parametre olarak maksimum standart uptake değeri $\left(S U V_{\text {maks }}\right)$ kullanıldı. Görsel değerlendirmede karaciğerden daha yüksek metabolik aktivite gösteren kemik iliği aktivitesi patolojik olarak değerlendirildi. Semikantitatif değerlendirmede ise kemik iliğinde diffüz metabolik aktivite artışı gösteren olgularda iliak kanattan, fokal tutulumda ise en yüksek aktivite gösteren alandan ilgi alanı çizdirilerek SUV maks değeri hesaplandı. KiB sonuçları referans olarak alınmıştır.

Bulgular: Tüm olgular için görsel değerlendirmede PET/BT'nin kemik iliği infiltrasyonunu göstermede duyarlı̆̆ı \%31, özgüllüğü \%85 olarak saptanmıştır. HL olgularında görsel değerlendirmede duyarlılık \%80, özgüllük \%78; NHL olgularında ise duyarlılık \%24, özgüllük \%90 olarak bulunmuştur. Semikantitatif değerlendirmede $H_{L}$ 'de $S V_{\text {maks }} \geq 4$ alındığında duyarlıık \%80, özgüllük \%68 olarak saptanmıştır. NHL'de ise $\mathrm{SUV}_{\text {maks }} \geq 3,2$ olarak belirlendiğinde duyarlılık \%65, özgüllük \%58 olarak bulunmuştur.

Sonuç: Bu çalışmada, çok yüksek olmamakla birlikte, PET/BT bulguları ile KiB sonuçları arasında uyum izlendi. PET/BT görüntülemenin kemik iliği infiltrasyonu olup olmadığını göstermede etkili bir yöntem olduğunu görmekteyiz. PET/BT'nin, KiB’nin yerini almamakla birlikte, biyopsi yapılabilecek bölgeyi göstermede yönlendirici ve KiB'yi tamamlayıcı bir görüntüleme yöntemi olarak kullanılabileceğini düşünmekteyiz.

Anahtar kelimeler: Hodgkin lenfoma, non-Hodgkin lenfoma, pozitron emisyon tomografisi/bilgisayarlı tomografi, kemik iliği biyopsisi

\section{Introduction}

Accurate staging of lymphomas is essential both to implement effective treatment protocols and minimize side effects (1). Identification of bone marrow infiltration (BMI) has an important role in staging (2). Bone marrow involvement indicates generalized disease in lymphoma patients, and the standard method established for its evaluation is bone marrow biopsy (BMB). BMB from unilateral iliac crest is the routine first-line method used for staging $(3,4)$. However, this method has certain limitations since it is an invasive method and allows for evaluation of a limited part of the bone marrow. BMI can also be detected by imaging techniques. Computerized tomography (CT) detects cortical bone lesions and late stage bone changes. However, it has a low sensitivity rate for detecting early stage changes (5). Magnetic resonance (MR) is not used in routine practice since it is a sensitive but costly technique, which needs longer imaging time and is anatomically limited.

Currently, 18F-2-fluoro-2-deoxy-D-glucose (18F-FDG) positron emission tomography (PET/CT) is being successfully used for both staging and follow-up of Hodgkin's lymphoma $(\mathrm{HL})$ and non-Hodgkin's lymphoma (NHL) $(2,6,7)$. Various studies have demonstrated that PET/CT effectively detects bone marrow involvement and is concordant with $\mathrm{BMB}$ findings $(1,5,8)$. Thus, it is deemed as a complementary method (9). This study aimed to evaluate the efficacy of 18F-FDG-PET/CT in detection of BM infiltration in $\mathrm{HL}$ and $\mathrm{NHL}$.

\section{Materials and Methods}

\section{Patients}

This study, approved by the Akdeniz University Medical School Local Ethics Committee, included histopathologically confirmed, treatment naïve 172 lymphoma cases (50 F, 122 $\mathrm{M}$; age interval 3-85; mean age 45.37 $\pm 21.14 ; 64 \mathrm{HL}, 108$ $\mathrm{NHL}$ ) who underwent initial staging with PET/CT at Akdeniz University Medical School Department of Nuclear Medicine between July 2009 and December 2013. Patients included in the study did not have other concomitant malignancies. Additionally, patients did not receive any bone marrow stimulation therapy before PET/CT scanning. The maximum interval between PET/CT scan and BMB was 10 days.

\section{Positron Emission Tomography/Computerized Tomography Scanning}

Intravenous $0.1 \mathrm{mCi} / \mathrm{kg}$ 18F-FDG was administered to each patient following 6 hours of fasting, with a blood glucose level below $200 \mathrm{mg} / \mathrm{dL}$. The intravenous/oral contrast agent was administered. After 45-60 minutes of waiting period, PET/CT images were acquired from the vertex to the upper thigh with Siemens Biograph True Point PET/CT scanner (CT section thickness $3 \mathrm{~mm}, 110 \mathrm{mAs}, 120 \mathrm{kV}$; 3 minutes per-bed PET) (Siemens, Erlangen, Germany) at the PET/CT unit. Attenuation corrected PET, CT and fusion PET/CT images were reviewed simultaneously; visual and semiquantitative assessments were performed. The maximum standard uptake value $\left(S U V_{\max }\right)$ was the 
quantitative parameter used for 18F-FDG-PET scan. In visual assessment, bone marrow metabolic activity that is greater than the liver was considered to be pathologic. For semiquantitative assessment, regions of interest (ROI) were drawn for SUV max estimation, which included iliac crest in cases with diffusely increased metabolic activity and the highest activity area in cases with focal involvement.

\section{Bone Marrow Biopsy}

Unilateral BMB of the posterior iliac crest was performed by different hematologists as part of routine clinical evaluation, and the presence of marrow infiltration was interpreted by an experienced hematopathologist who was blinded to the PET/CT results. Trephine biopsy samples were analyzed following the standard procedures. BMB was considered as positive in the presence of lymphoma involvement. Although flow cytometric immunophenotyping of marrow aspirates can be performed, this method was not used for the diagnosis of bone marrow involvement.

\section{Data Analysis}

BM biopsy results were regarded as the reference test for evaluating BMI.

Cases with concordant findings in both PET/CT and BMB (both positive or negative) were evaluated as true positive or true negative results. Non-concordance between these two parameters was described as false negativity or false positivity. The sensitivity and specificity rates, positive predictive value (PPV) and negative predictive value (NPV) of PET/CT for detecting BM infiltration were determined for all cases. Additionally, receiver operating characteristics (ROC) curves were formed to determine cut-off values for SUV max. Analyzes were performed with PASW 18 (SPSS/IBM, Chicago, IL, USA) software.

\section{Results}

Among the 172 cases, BMI was detected by PET/CT in $33(19.1 \%)$ and by BMB in $42(24.4 \%)$ patients (Table 1). Among the 33 cases with infiltration on PET/CT, 11 had diffuse heterogeneous patchy accumulations while 22 had unifocal/multifocal accumulations. Within the $64 \mathrm{HL}$ patients, BMI was detected by PET/CT in 17 (26.5\%) and by $\mathrm{BMB}$ in 5 (7.8\%) (Table 2), while among the $108 \mathrm{NHL}$ patients, BMI was detected by PET/CT in 16 (14.8\%) and by BMB in 37 (34.2\%) (Table 3).

Concordance between PET/CT and BMB was observed in $123(71 \%)$ of 172 patients. Both tests were negative in 110 patients and both were reported positive in 13 patients. A concordance between PET/CT and BMB was detected in $50(78 \%) \mathrm{HL}$ patients, both tests were negative in 46 and positive in 4 patients. Non-concordance was observed in 14 (22\%) of these patients, 13 patients were positive on PET/ $\mathrm{CT}$ but negative on $\mathrm{BMB}$ while 1 patient was positive on $\mathrm{BMB}$ but negative on PET/CT. Concordance was detected in $73(67 \%) \mathrm{NHL}$ patients, both tests were negative in 64 and positive in 9 patients. The tests were non-concordant in 35 patients, 7 patients were positive on PET/CT but negative on $\mathrm{BMB}$ while 28 patients were positive on $\mathrm{BMB}$ but negative on PET/CT.

On visual assessment of all the cases, PET/CT was found to have a $31 \%$ sensitivity and $85 \%$ specificity rate for detection of BMI with 39\% PPV and 79\% NPV (Table 4). Visual assessment of HL cases showed $80 \%$ sensitivity, $78 \%$ specificity with 24\% PPV and 98\% NPV (Table 4), while in $\mathrm{NHL}$ cases the corresponding values were 24\%, 90\%, 56\% and $70 \%$, respectively (Table 4 ).

Table 1. Distribution of the patients according to positron emission tomography/computerized tomography and bone marrow biopsy test results

\begin{tabular}{|c|c|c|c|}
\hline Key & & & \\
\hline \multicolumn{4}{|l|}{$\begin{array}{l}\text { frequency } \\
\text { row percentage } \\
\text { column percentage }\end{array}$} \\
\hline \multicolumn{4}{|c|}{ BM } \\
\hline PET & Negative & Positive & Total \\
\hline Negative & $\begin{array}{l}110 \\
79.14 \\
84.62\end{array}$ & $\begin{array}{l}29 \\
20.86 \\
69.05\end{array}$ & $\begin{array}{l}139 \\
100.00 \\
80.81\end{array}$ \\
\hline Positive & $\begin{array}{l}20 \\
60.61 \\
15.38\end{array}$ & $\begin{array}{l}13 \\
39.39 \\
30.95\end{array}$ & $\begin{array}{l}33 \\
100.00 \\
19.19\end{array}$ \\
\hline Total & $\begin{array}{l}130 \\
75.58 \\
100.00\end{array}$ & $\begin{array}{l}42 \\
24.42 \\
100.00\end{array}$ & $\begin{array}{l}172 \\
100.00 \\
100.00\end{array}$ \\
\hline
\end{tabular}

PET: Positron emission tomography/computerized tomography, BM: Bone marrow

Table 2. Distribution of the Hodgkin's lymphoma patients according to positron emission tomography/computerized tomography and bone marrow biopsy test results

\begin{tabular}{|c|c|c|c|}
\hline Key & & & \\
\hline \multicolumn{4}{|l|}{$\begin{array}{l}\text { frequency } \\
\text { row percentage } \\
\text { column percentage }\end{array}$} \\
\hline \multicolumn{4}{|c|}{ BM } \\
\hline PET & Negative & Positive & Total \\
\hline Negative & $\begin{array}{l}46 \\
97.87 \\
77.97\end{array}$ & $\begin{array}{l}1 \\
2.13 \\
20.00\end{array}$ & $\begin{array}{l}47 \\
100.00 \\
73.44\end{array}$ \\
\hline Positive & $\begin{array}{l}13 \\
76.47 \\
22.03\end{array}$ & $\begin{array}{l}4 \\
23.53 \\
80.00\end{array}$ & $\begin{array}{l}17 \\
100.00 \\
26.56\end{array}$ \\
\hline Total & $\begin{array}{l}59 \\
92.19 \\
100.00\end{array}$ & $\begin{array}{l}5 \\
7.81 \\
100.00\end{array}$ & $\begin{array}{l}64 \\
100.00 \\
100.00\end{array}$ \\
\hline
\end{tabular}

PET: Positron emission tomography/computerized tomography, BM: Bone marrow 
Semiquantitative assessment was performed using $S U V_{\max }$ values and ROC curves based on BMB findings. Area under the ROC curve (AUC) estimated for all patients was 0.6386 , that of $\mathrm{HL}$ patients was 0.7763 and NHL patients was 0.6534 . Cut-off, sensitivity and specificity values were

Table 3. Distribution of the non-Hodgkin's lymphoma patients according to positron emission tomography/ computerized tomography and bone marrow biopsy test results

\begin{tabular}{|c|c|c|c|}
\hline Key & & & \\
\hline \multicolumn{4}{|l|}{$\begin{array}{l}\text { frequency } \\
\text { row percentage } \\
\text { column percentage }\end{array}$} \\
\hline \multicolumn{4}{|c|}{ BM } \\
\hline PET & Negative & Positive & Total \\
\hline Negative & $\begin{array}{l}64 \\
69.57 \\
90.14\end{array}$ & $\begin{array}{l}28 \\
30.43 \\
75.68\end{array}$ & $\begin{array}{l}92 \\
100.00 \\
85.19\end{array}$ \\
\hline Positive & $\begin{array}{l}7 \\
43.75 \\
9.86\end{array}$ & $\begin{array}{l}9 \\
56.25 \\
24.32\end{array}$ & $\begin{array}{l}16 \\
100.00 \\
14.81\end{array}$ \\
\hline Total & $\begin{array}{l}71 \\
65.74 \\
100.00\end{array}$ & $\begin{array}{l}37 \\
34.26 \\
100.00\end{array}$ & $\begin{array}{l}108 \\
100.00 \\
100.00\end{array}$ \\
\hline
\end{tabular}

PET: Positron emission tomography/computerized tomography, BM: Bone marrow estimated using ROC curves for all patients and $\mathrm{HL}$ and $\mathrm{NHL}$ patient subgroups. The results were as follows, respectively; cut-off 3.5, 4, 3.2; sensitivity 59\%, 80\%,65\%; specificity $62 \%, 68 \%, 58 \%$ (Table 5).

Estimated mean SUV max value was $12.02 \mathrm{~g} / \mathrm{mL}$ for the 33 patients with positive findings on $\mathrm{PET} / \mathrm{CT} ; 11.67 \mathrm{~g} / \mathrm{mL}$ for 13 patients who were positive on both $\mathrm{PET} / \mathrm{CT}$ and $\mathrm{BMB}$; and $12.25 \mathrm{~g} / \mathrm{mL}$ for 20 patients who were positive on PET/ CT but negative on BMB (Table 6).

\section{Discussion}

Initial evaluation including determination of anatomic distribution of the disease extent is an essential factor to predict both disease-free and overall survival in lymphoma patients. BM involvement in lymphoma indicates generalized disease and is a predictor of poor prognosis. Besides the role of BMI in primary staging, it has a specific clinical significance for guiding the treatment approach (2). In routine clinical practice, BMB is used to evaluate $\mathrm{BM}$ involvement. Although $\mathrm{BMB}$ is primarily a safe and risk-free procedure, complications such as bleeding or infection can rarely occur. Additionally, being an invasive and painful procedure can be a disadvantage for patients. In case of insufficient sampling, repeated biopsies may be required. There is no consensus on whether BMB should be performed uni- or bi-laterally, thus biopsies are usually

Table 4. Sensitivity, specificity, positive predictive value and negative predictive value (95\% confidence interval) of positron emission tomography/computerized tomography with respect to bone marrow biopsy in the whole population and Hodgkin's lymphoma and non-Hodgkin's lymphoma subgroups

\begin{tabular}{llllll}
\hline & $\mathbf{n}$ & Sensitivity & Specificity & Positive predictive value & Negative predictive value \\
\hline All patients & 172 & $30.95 \%$ & $84.62 \%$ & $39.39 \%$ & $79.14 \%$ \\
Hodgkin lymphoma & 64 & $80 \%$ & $77.97 \%$ & $23.53 \%$ & $97.87 \%$ \\
Non-Hodgkin lymphoma & 108 & $24.32 \%$ & $90.14 \%$ & $56.25 \%$ & $69.57 \%$
\end{tabular}

Table 5. Receiver operating characteristics estimated area under curve with $95 \%$ confidence intervals, cut off, sensitivity and specificity values for the whole population and for Hodgkin's lymphoma and non-Hodgkin's lymphoma subgroups

\begin{tabular}{|c|c|c|c|}
\hline & All patients & HL & NHL \\
\hline AUC & 0.6386 & 0.7763 & 0.6534 \\
\hline Cut off & 3.5 & 4 & 3.2 \\
\hline Sensitivity & $59 \%$ & $80 \%$ & $65 \%$ \\
\hline Specificity & $62 \%$ & $68 \%$ & $58 \%$ \\
\hline
\end{tabular}

AUC: Area under curve, HL: Hodgkin's lymphoma, NHL: Non-Hodgkin's lymphoma

Table 6. Numeric distribution and mean maximum standard uptake values for patients with positive results on positron emission tomography/computerized tomography

\begin{tabular}{llll}
\hline & PET/CT (+) & PET/CT (+)/BMB (+) & PET/CT (+)/ BMB (-) \\
\hline $\mathrm{n}$ & 33 & 13 & 20 \\
Mean SUV & 12.02 & 11.67 & 12.25 \\
\hline
\end{tabular}

PET/CT: Positron emission tomography/computerized tomography, SUV max $_{\text {: }}$ Maximum standard uptake value, BMB: Bone marrow biopsy 
obtained from unilateral iliac crest blindly, which may lead to high false negative rates. In light of the mentioned reasons, there is growing interest in the search for accurate non-invasive methods to evaluate BMI. 18F-FDG-PET/CT is a hybrid imaging technique used for primary staging, evaluating treatment response, re-staging and for follow-up after complete remission in lymphoma patients. Although, due to the limited number of studies, its role in evaluating bone/BM involvement is not well established, available results in the literature are promising $(5,8)$.

Studies in the literature include mixed populations involving both $\mathrm{HL}$ and NHL patients. Cortés-Romera et al. (10) evaluated 18F-FDG-PET/CT performance for detecting BMI with reference to $\mathrm{BMB}$ in their study on 147 patients, comprising of 84 diffuse large B-cell lymphoma (DLBCL) and $63 \mathrm{HL}$ patients. This study showed concordance between the two tests in 128 patients (87\%) (74 DLBCL, $54 \mathrm{HL}$ ). Among these, both tests were reported positive in 21 and negative in 107 patients. Non-concordance was observed in 19 (14\%) patients, 18 of which had negative BMB results although involvement was detected on 18F-FDG-PET/CT, indicating $\mathrm{BMB}$ was not obtained from active involvement sites. As a result of this study, 18F-FDG-PET/CT was reported to be $95 \%$ sensitive, $86 \%$ specific with $87 \%$ accuracy, $54 \%$ PPV and 99\% NPV for detecting BMI. It was concluded that 18F-FDG-PET/CT had higher BMI detection rates in DLBCL and $\mathrm{HL}$ patients and in serving as a guide to biopsy sites, and that it can be used as a supplement to BMB (10).

In our study, among the 172 patients, 64 were diagnosed as $\mathrm{HL}$ and 108 as NHL. Thirty-three (19.1\%) patients were found positive by 18F-FDG-PET/CT and 42 (24.4\%) were positive on BMB. Concordance between the two tests was observed in 123 of the 172 patients (71\%). Both tests were reported negative in 110 patients and both were positive in 13. Based on the total study population in the current study, 18F-FDG-PET/CT was detected to have 31\% sensitivity and $85 \%$ specificity rate in detecting BMI with 39\% PPV and $79 \%$ NPV. Additionally, AUC and cut-off values for the whole study population were 0.6386 and 3.5, respectively.

Similar studies on separate groups of $\mathrm{HL}$ and $\mathrm{NHL}$ patients are also available in the literature. In the study by Muzahir et al. (11), BMB from bilateral iliac crests were obtained from $122 \mathrm{HL}$ patients and 18F-FDG-PET/CT findings were compared to these results that are considered as the gold standard. Accordingly, 18F-FDG-PET/CT was found to be 100\% sensitive, $76.57 \%$ specific for detecting $\mathrm{BMI}$ in $\mathrm{HL}$ patients, with $78.62 \%$ diagnostic accuracy, $76.57 \%$ NPV and $29.72 \%$ PPV. The high sensitivity of $18 \mathrm{~F}-\mathrm{FDG}-\mathrm{PET} / \mathrm{CT}$ in this study was attributed to the positive 18F-FDG-PET/CT results in all of the BMB positive patients (11).

In the meta-analysis by Cheng and Alavi (12) including 7 studies comprising a total of $687 \mathrm{HL}$ patients, 18F-FDG-PET/ CT was found superior to BMB in detecting BMI. Pooled sensitivity of 18F-FDG-PET/CT was determined as $94.5 \%$ [95\% confidence interval ( $\mathrm{Cl})$ : 89.0-97.8\%] whereas the corresponding estimate for BMB was 39.4\% (95\% Cl: 30.8$48.8 \%)$.

In the study by Adams et al. (13) on 26 newly diagnosed HL patients, visual 18F-FDG-PET/CT results were compared to $\mathrm{BMB}$ of the right iliac crest, which is used as the gold standard method. Accordingly, 18F-FDG-PET/CT was found to be $100 \%$ sensitive (95\% Cl: 51.1-100\%), 100\% specific (95\% Cl: 81.8-100\%) in detecting BMI with 100\% (95\% Cl: 51.1-100\%) PPV, 100\% (95\% Cl: 81.8$100 \%)$ NPV. Additionally, SUV $\max$ of BMB positive patients [mean \pm standard deviation (SD): $3.4 \pm 0.85$ ] was higher than that of BMB negative patients almost reaching statistical significance (mean \pm SD 2.7 \pm 0.63$)(p=0.052)(13)$.

In our study, 64 of the 172 patients were diagnosed with $\mathrm{HL}$. Concordance between BMB and 18F-FDG-PET/CT was observed in 50 (78\%) of the 64 patients. Among these 50 cases, both tests were negative in 46 and positive in 4 . In the remaining 14 patients, 13 were 18F-FDG-PET/CT positive, $B M B$ negative and one patient was $B M B$ positive without any involvement on 18F-FDG-PET/CT. Thus, considering $\mathrm{BMB}$ as the gold standard, 18F-FDG-PET/CT was found to be $80 \%$ sensitive, $78 \%$ specific for detecting BMI with $24 \%$ PPV and 98\% NPV. The high sensitivity and specificity values were consistent with the literature. On semi-quantitative assessment, there was no significant difference in SUV $\max$ values between $\mathrm{BMB}$ positive and negative cases among the PET/CT positive patients. Additionally, in our study, AUC and cut-off values for $\mathrm{HL}$ patients were found as 0.7763 and 4 , respectively.

Similar studies on NHL patients are also available in the literature. In the study by Muslimani et al. (14), $97 \mathrm{NHL}$ patients were grouped according to the presence of low or high grade disease, and the results of 18F-FDG-PET/CT scan for initial staging and unilateral iliac crest BMB were compared. Unlike other studies in the literature, samples were obtained from the involvement sites in BMB-negative patients with 18F-FDG-PET/CT images suggesting BMI. Consequently, BMB from sites of involvement of the 11 patients who were initially BMB-negative and 18F-FDG$\mathrm{PET} / \mathrm{CT}$ positive, revealed 6 positive $\mathrm{BMB}$ results. Positive repeat biopsies were obtained from the contralateral iliac crest in 1, from the humerus in 2, from the tibia in 1 and from the fourth vertebra in one patient. Thus, 18F-FDGPET/CT was $79 \%$ sensitive, $91 \%$ specific for detecting BMI with $87 \%$ PPV and $87 \%$ NPV. Additionally, there was no significant difference between the low and high grade $\mathrm{NHL}$ groups in terms of the ability of 18F-FDG-PET to detect BMI (sensitivity $p=0.23$, specificity $p=0.64$ ). In conclusion, the high potential of 18F-FDG-PET in detecting BMI in NHL was highlighted and $\mathrm{BMB}$ sampling was recommended for $\mathrm{BMB}$ negative patients whose 18F-FDG-PET scan demonstrates BM involvement (14). In our study, biopsies were obtained only from the iliac crest and not from other sites observed positive on PET/CT, which is a limitation of our study. We could have found higher sensitivity and specificity values if 
biopsy sampling was done from sites other than the iliac crest in cases who were biopsy negative. Many studies in the literature have reported that in the majority of BMBnegative cases multifocal involvement was observed on 18F-FDG-PET/CT and that biopsies obtained from the sites of involvement were almost always positive $(5,15,16,17)$.

In our study, among the 33 cases with infiltration on PET/ $\mathrm{CT}, 11$ had diffuse heterogeneous patchy accumulations. Diffuse accumulations may be secondary to benign conditions such as inflammation, thus some studies (13) have excluded such cases while others have not (11). In our study diffuse accumulations were heterogeneous and patchy, thus they were included since they were not homogenous lesions.

In the study by Lee et al. (18), 120 high grade NHL patients comprised of newly diagnosed DLBCL and peripheral T-cell lymphoma cases were included to assess the role of $18 \mathrm{~F}-\mathrm{FDG}-\mathrm{PET} / \mathrm{CT}$ in the detection of BMI. Bilateral iliac crest $\mathrm{BMB}$ results were considered the gold standard. 18F-FDG-PET/CT and BMB results were concordant in 100 of the 120 patients (both positive or negative) while 20 were non-concordant. Besides, SUV $\max$ values of patients demonstrating abnormal 18F-FDG accumulation were significantly higher as compared to those with normal 18F-FDG accumulation. It was concluded that 18F-FDG-PET/ $\mathrm{CT}$ and $\mathrm{BMB}$ are complementary techniques in assessing $\mathrm{BMI}$ in patients with high-grade lymphomas, and obtaining biopsies from sites of accumulation was recommended for patients showing 18F-FDG-avidity although standard iliac crest BMB are negative (18).

Berthet et al. (19) evaluated 18F-FDG-PET/CT performance for detecting $\mathrm{BMI}$ with reference to $\mathrm{BMB}$ and its effect on progression-free/overall survival in their study on 142 patients with DLBCL. In case of negative BMB, 18F-FDGPET/CT accumulation areas were evaluated by biopsy or MR images. Accordingly, as compared to BMB, 18F-FDGPET/CT had significantly higher sensitivity (94\% vs. $24 \%$, p<0.001), NPV (98\% vs. $80 \%$ ) and accuracy ( $98 \%$ vs. $81 \%$ ). Multivariate analysis showed that BMI detected by 18 F-FDGPET/CT was an independent predictor of progression-free survival (PFS) $(p=0.02)$ but not for overall survival. It was concluded that, assessment of BMI with 18F-FDG-PET/CT has higher diagnostic and prognostic prediction in newly diagnosed DLBCL patients as compared to BMB (19).

Zhou et al. (20) evaluated the role of 18F-FDG-PET/CT in detecting BMI and compared overall (OS) and PFS rates of patients who were concordantly negative (PET-CT/ BMB-) or positive (PET-CT/BMB+) in 55 patients with newly diagnosed extranodal natural killer/T cell lymphoma. Using $B M B$ results as reference, the study found the sensitivity and specificity rates of 18F-FDG-PET/CT for detecting BMI as $100 \%$ and $86 \%$, respectively. Following the median follow-up period of 16 months (range, 3-43 months) PET$\mathrm{CT} / \mathrm{BMB}$ positive patient group showed worsened 2-year OS as compared to PET-CT/BMB negative group (84.8\% vs. $67.9 \%, p<0.05)$. On the other hand, the estimated 2-year PFS rates for PET-CT/BMB negative and PET-CT/BMB positive patients were $72.7 \%$ and $41.9 \%$, respectively. However, it was concluded that, due to the small number of PET-CT/BMB positive patients, it would be incorrect to conclude that survival rates were similar for both groups in advanced stage patients. Finally, the prognostic and complementary diagnostic role of 18F-FDG-PET/CT in detecting BMI, especially in cases missed by BMB, was underlined (20).

In our study, 108 of the 172 patients had NHL diagnosis and among these $16(14.8 \%)$ were 18F-FDG-PET/CT positive and 37 (34.2\%) were BMB positive. Subtyping/ grading was not performed for NHL patient group. Concordance between the two tests was observed in $73(67 \%)$ patients; 64 patients were PET-CT/BMB negative while 9 patients were PET-CT/BMB positive. Non-concordance was observed in 35 patients; of which 7 were 18F-FDG-PET/CT positive, BMB negative and the remaining 28 patients were BMB positive, 18F-FDG-PET/ $\mathrm{CT}$ negative. As a result, 18F-FDG-PET/CT was found to be $24 \%$ sensitive, $90 \%$ specific for detecting BMI with PPV $56 \%$ and NPV $70 \%$. We suggest that the low sensitivity for the NHL subgroup may be due to the lack of histological subgrouping in this patient group. Studies have reported higher 18F-FDG-PET/CT sensitivity rates in detecting $\mathrm{BMI}$ in aggressive NHL subtypes, while $2 / 3$ false negativity ratio was observed in indolent histological forms (e.g., grade 1 and 2 follicular lymphomas) leading to lower sensitivity values (9). Additionally, in our study, AUC and cut-off values for NHL patients were found as 0.6534 and 3.2 , respectively.

\section{Conclusion}

In this study, a moderately high concordance $(71 \%)$ was observed between PET/CT and BMB findings. The rate of concordance was higher in $\mathrm{HL}$ patients $(78 \%)$ as compared to NHL patients (67\%). In conclusion, PET/CT appears to be a significant method for detecting BM infiltration in comparison to BM biopsy which is an invasive method. Currently, BM biopsy is usually performed from the iliac crest while PET/CT has the advantage of whole body imaging to allow for detection of involvement sites other than the iliac bone. In this regard, although PET/CT is not a substitute for BM biopsy, we suggest that it can be used as a guide to biopsy site and a complementary imaging technique for BM biopsy.

\section{Ethics}

Ethics Committee Approval: The study was approved by the Akdeniz University Local Ethics Committee (date: 21.01.2015) (protocol number: 35), Informed Consent: Consent form was filled out by all participants.

Peer-review: Externally peer-reviewed. 


\section{Authorship Contributions}

Surgical and Medical Practices: O.S., O.K.Y., L.U., Concept: A.O.Ö., E.S.B., F.A., Design: A.O.Ö., E.S.B., F.A., Data Collection or Processing: A.O.Ö., F.A., B.A., O.S., Analysis or Interpretation: A.O.Ö., F.A., T.T., A.B., A.Y., F.G., Literature Search: A.O.Ö., E.S.B., Writing: A.O.Ö., E.S.B., F.A.

Conflict of Interest: No conflict of interest was declared by the authors.

Financial Disclosure: The authors declared that this study received no financial support.

\section{References}

1. Pelosi E, Penna D, Deandreis D, Chiappella A, Skanjeti A, Vitolo U, Bisi G. FDG-PET in the detection of bone marrow disease in Hodgkin's disease and aggressive non-Hodgkin's lymphoma and its impact on clinical management. Q J Nucl Med Mol Imaging 2008;52:9-16.

2. Stumpe KD, Urbinelli M, Steinert HC, Glanzmann C, Buck A, von Schulthess GK. Whole-body positron emission tomography using fluorodeoxyglucose for staging of lymphoma: effectiveness and comparison with computed tomography. Eur J Nucl Med 1998;25:721-728.

3. Brusamolino E, Bacigalupo A, Barosi G, Biti G, Gobbi PG, Levis A, Marchetti M, Santoro A, Zinzani PL, Tura S. Classical Hodgkin's lymphoma in adults: guidelines of the Italian Society of Hematology, the Italian Society of Experimental Hematology, and the Italian Group for Bone Marrow Transplantation on initial work-up, management, and follow-up. Haematologica 2009;94:550-565.

4. Howell SJ, Grey M, Chang J, Morgenstern GR, Cowan RA, Deakin DP, Radford JA. The value of bone marrow examination in the staging of Hodgkin's lymphoma: a review of 955 cases seen in a regional cancer centre. Br J Haematol 2002;119:408-411.

5. Moulin-Romsee G, Hindié E, Cuenca X, Brice $P$, Decaudin D, Bénamor $M$, Brière J, Anitei $M$, Filmont JE, Sibon $D$, de Kerviler $E$, Moretti JL. 18F-FDG-PET/CT bone/bone marrow findings in Hodgkin's lymphoma may circumvent the use of bone marrow trephine biopsy at diagnosis staging. Eur J Nucl Med Mol Imaging 2010;37:1095-1105.

6. Buchmann I, Moog F, Schirrmeister H, Reske SN. Positron emission tomography for detection and staging of malignant lymphoma. Recent Results Cancer Res 2000;156:78-89.

7. Kostakoglu L, Coleman M, Leonard JP, Kuji I, Zoe H, Goldsmith SJ. PET predicts prognosis after 1 cycle of chemotherapy in aggressive lymphoma and Hodgkin's disease. J Nucl Med 2002;43:1018-27.

8. Moog F, Bangerter M, Kotzerke J, Guhlmann A, Frickhofen N, Reske SN. 18-F-fluorodeoxyglucose-positron emission tomography as a new approach to detect lymphomatous bone marrow. J Clin Oncol 1998;16:603-609.

9. Fuster D, Chiang S, Andreadis C, Guan L, Zhuang H, Schuster S, Alavi A. Can [18F]fluorodeoxyglucose positron emission tomography imaging complement biopsy results from the iliac crest for the detection of bone marrow involvement in patients with malignant lymphoma? Nucl Med Commun 2006;27:11-15.
10. Cortés-Romera M, Sabaté-Llobera A, Mercadal-Vilchez S, ClimentEsteller F, Serrano-Maestro A, Gámez-Cenzano C, GonzalezBarca E. Bone marrow evaluation in initial staging of lymphoma: 18F-FDG-PET/CT versus bone marrow biopsy. Clin Nucl Med 2014;39:46-52.

11. Muzahir S, Mian M, Munir I, Nawaz MK, Faruqui ZS, Mufti KA, Bashir $\mathrm{H}$, Uddin N, Siddiqui N, Maaz AU, Mahmood MT. Clinical utility of $18 \mathrm{~F}$ FDG-PET/CT in the detection of bone marrow disease in Hodgkin's lymphoma. Br J Radiol 2012;85:490-496.

12. Cheng G, Alavi A. Value of 18F-FDG-PET versus iliac biopsy in the initial evaluation of bone marrow infiltration in the case of Hodgkin's disease: a meta-analysis. Nucl Med Commun 2013;34:25-31.

13. Adams HJ, Kwee TC, Fijnheer R, Dubois SV, Nievelstein RA, de Klerk JM. Bone marrow FDG-PET/CT in Hodgkin lymphoma revisited: do imaging and pathology match? Ann Nucl Med 2015;29:132137.

14. Muslimani AA, Farag HL, Francis S, Spiro TP, Chaudhry AA, Chan VC, Taylor HC, Daw HA. The utility of 18-F-fluorodeoxyglucose positron emission tomography in evaluation of bone marrow involvement by non-Hodgkin lymphoma. Am J Clin Oncol 2008;31:409-412.

15. Cheng G, Chen W, Chamroonrat W, Torigian DA, Zhuang H, Alavi A. Biopsy versus FDG-PET/CT in the initial evaluation of bone marrow involvement in pediatric lymphoma patients. Eur J Nucl Med Mol Imaging 2011;38:1469-1476.

16. Ribrag $V$, Vanel $D$, Leboulleux $S$, Lumbroso J, Couanet $D$, Bonniaud $G$, Aupérin A, Masson F, Bosq J, Edeline $V$, Fermé C, Pigneur $F$, Schlumberger $\mathrm{M}$. Prospective study of bone marrow infiltration in aggressive lymphoma by three independent methods: whole-body MRI, PET/CT and bone marrow biopsy. Eur J Radiol 2008;66:325331.

17. Purz S, Mauz-Körholz C, Körholz D, Hasenclever D, Krausse $A$ Sorge I, Ruschke K, Stiefel M, Amthauer H, Schober O, Kranert WT, Weber WA, Haberkorn U, Hundsdörfer P, Ehlert K, Becker M, Rössler J, Kulozik AE, Sabri O, Kluge R. [18F]Fluorodeoxyglucose positron emission tomography for detection of bone marrow involvement in children and adolescents with Hodgkin's lymphoma. J Clin Oncol 2011:29:3523-3528

18. Lee $\mathrm{Y}$, Hwang $\mathrm{KH}$, Hong J, Park J, Lee JH, Ahn JY, Kim JH, Lee $H$, Kim SG, Shin JY. Usefulness of (18)F-FDG-PET/CT for the Evaluation of Bone Marrow Involvement in Patients with HighGrade Non-Hodgkin's Lymphoma. Nucl Med Mol Imaging 2012;46:269-277.

19. Berthet $L$, Cochet $A$, Kanoun $S$, Berriolo-Riedinger $A$, Humbert $O$, Toubeau M, Dygai-Cochet I, Legouge C, Casasnovas O. In newly diagnosed diffuse large B-cell lymphoma, determination of bone marrow involvement with 18F-FDG-PET/CT provides better diagnostic performance and prognostic stratification than does biopsy. J Nucl Med 2013;54:1244-1250.

20. Zhou Z, Chen C, Li X, Li Z, Zhang X, Chang Y, Lu L, Cui Y, Ma Y, Zhang M. Evaluation of bone marrow involvement in extranodal NK/T cell lymphoma by FDG-PET/CT. Ann Hematol 2015;94:963-967. 